\title{
PENGARUH MOTIVASI KERJA GURU, DISIPLIN KERJA GURU, DAN KEDISIPLINAN SISWA TERHADAP PRESTASI BELAJAR SISWA
}

\author{
Nastiti Amalda, Lantip Diat Prasojo \\ Prodi Manajemen Pendidikan PPs UNY, Universitas Negeri Yogyakarta \\ nastiti.amalda@gmail.com, lantip1975@gmail.com
}

\begin{abstract}
Abstrak
Penelitian ini bertujuan untuk mengetahui pengaruh faktor motivasi kerja guru, disiplin kerja guru, dan kedisiplinan siswa terhadap prestasi belajar siswa SMA/MA di Kota Mataram. Penelitian ini adalah penelitian korelasional dengan pendekatan kuantitatif dengan sasaran guru dan siswa SMA/MA di Kota Mataram. Instrumen pengumpul data berupa angket. Validitas instrumen berupa validitas logis dan validitas empiris yang dihitung dengan Pearson Product Moment. Reliabilitasnya dihitung dengan rumus Alpha Cronbach. Teknik analisis data yang digunakan adalah regresi sederhana dan regresi berganda. Hasil penelitian ini adalah sebagai berikut: (1) terdapat pengaruh antara motivasi kerja guru terhadap prestasi belajar siswa SMA/MA di Kota Mataram sejumlah 13,1\%; (2) terdapat pengaruh antara disiplin kerja guru terhadap prestasi belajar siswa SMA/MA di Kota Mataram sejumlah 9,9\%; (3) terdapat pengaruh antara kedisiplinan siswa terhadap prestasi belajar siswa SMA/MA di Kota Mataram sejumlah 7,8\%; (4) motivasi kerja guru, disiplin kerja guru dan kedisiplinan siswa secara bersama-sama mempengaruhi prestasi belajar siswa SMA/MA di Kota Mataram sejumlah 34\%.
\end{abstract}

Kata Kunci: Prestasi belajar siswa, motivasi kerja guru, disiplin kerja guru, kedisiplinan siswa.

\section{THE INFLUENCE OF TEACHERS' WORK MOTIVATION, TEACHERS' WORK DISCIPLINE AND STUDENTS' DISCIPLINE ON STUDENTS' LEARNING ACHIEVEMENT}

\author{
Nastiti Amalda, Lantip Diat Prasojo \\ Prodi Manajemen Pendidikan PPs UNY, Universitas Negeri Yogyakarta \\ nastiti.amalda@gmail.com, lantip1975@gmail.com
}

\begin{abstract}
This research aimed to reveal the effect of teachers' work motivation factor, teachers' work discipline, and students' discipline on students' learning achievement in senior high schools in Mataram. This research was correlational research with quantitative approach by targeting teachers' and students' of senior high schools in Mataram. The instrument to collect data was in the form of questionnaire. The validity of the instrument was in the form of logical validity and the empirical validity calculated by the Pearson Product Moment. Reliability was calculated by the Alpha Cronbach formula. The data analysis technique used was simple regression and multiple regression. The results of this study indicate that: (1) teachers' work motivation influences students' learning achievement in senior high schools in Mataram by 13.1\%; (2) teachers' work discipline influences students' achievement in senior high schools in Mataram by 9.9\%; (3) students' discipline influences students' achievement in senior high schools in Mataram by 7.8\%; (4) the teachers' work motivation, teachers' work discipline the and students' discipline together affect students' learning achievement in senior high schools in Mataram by $34 \%$.
\end{abstract}

Keywords: students' learning achievement, teachers' work motivation, teachers' work discipline, students' discipline. 


\section{Pendahuluan}

Pendidikan adalah usaha sadar dan terencana untuk mewujudkan suasana belajar dan proses pembelajaran agar peserta didik secara aktif mengembangkan potensi dirinya untuk memiliki kekuatan spiritual keagamaan, pengendalian diri, kepribadian kecerdasan, akhlak mulia serta keterampilan yang diperlukan dirinya, masyarakat, bangsa dan negara. Pendidikan mempunyai peran yang sangat strategis dalam meningkatkan kualitas sumber daya manusia dan upaya mewujudkan cita-cita bangsa Indonesia dalam mewujudkan kesejahteraan umum dan mencerdaskan kehidupan bangsa. Tercapainya tujuan pendidikan sangat ditentukan oleh berbagai unsur yang menunjangnya.

Dalam mewujudkan tujuan pendidikan nasional tersebut Pemerintah Kota Mataram telah memberikan perhatiannya, hal ini dapat kita cermati pada kebijakan Pemerintah Kota Mataram yang menempatkan pendidikan sebagai prioritas pembangunan yang utama. Namun, dengan kepeduliannya dibidang pendidikan berdasarkan data yang diperoleh dari Dinas Dikpora NTB tingkat atau hasil kelulusan Ujian Nasional (UN) jenjang SMA/MA tahun pelajaran 2012/2013, di Kota Mataram mencapai $99,75 \%$, atau sedikit lebih rendah dibandingkan dengan tahun sebelumnya yang mencapai 99,87\%. Ada penurunan tingkat kelulusan di tahun ini jika dibandingkan dengan tahun lalu.

Prestasi belajar siswa berdasarkan hasil UN tersebut juga tidak diimbangi dengan perilaku siswa yang baik dan taat terhadap aturan, hal ini terbukti dengan maraknya pelanggaran tata tertib yang dilakukan siswa baik itu di dalam lingkungan sekolah maupun di luar sekolah. Beberapa pelanggaran kedisiplinan antara lain pelanggaran tata tertib sekolah.

Guru harus mampu menerapkan kedisiplinan bagi dirinya serta anak didiknya. Dan guru harus mampu memberikan contoh yang baik serta mampu menerapkan kedisiplinan. Jika seorang guru belum mampu menerapkan kedisiplinan dengan baik, maka tidak akan berhasil kedisiplinan itu di terapkan pada siswa. Oleh karena itu, guru sebagai tolak ukur terciptanya kedisiplinan siswa harus mampu menerapkan kedisiplinan guru dengan baik, terutama dalam kegiatan pembelajaran dan dalam perilaku siswa.

Kedisiplinan akan terwujud dengan pembiasaan dan menumbuhkan kesadaran masing-masing warga sekolah dalam menegakkan tata tertib sekolah. Oleh karena itu dibutuhkan guru-guru yang mampu memberikan keteladan kedisiplinan. Hal tersebut dikarenakan siswa lebih banyak berinteraksi dengan guru-guru. Menurut Mulyasa (2009, p. 5) guru merupakan komponen yang paling berpengaruh terhadap terciptanya proses dan hasil pendidikan yang berkualitas.

Guru yang memiliki motivasi kerja tinggi, akan melakukan lebih dari sekedar rutinitasnya dalam mengajar sehingga produktivitas sekolah akan meningkat. Motivasi kerja merupakan kesedian untuk melaksanakan upaya tinggi untuk mencapai tujuan-tujuan keorganisasian yang dikondisikan oleh kemampuan upaya untuk memenuhi kebutuhan individual tertentu (Suwatno \& Priansa, 2011, p.171).

Prestasi adalah hasil yang dicapai oleh seorang individu yang merupakan hasil dari belajar. Sardiman (2010, p. 46) menyatakan prestasi adalah kemampuan nyata yang merupakan hasil interaksi antara berbagai faktor yang mempengaruhi baik dari dalam maupun dari luar individu dalam belajar. Belajar adalah sebuah proses perubahan yang terjadi pada kepribadian seorang manusia dan perubahan tersebut ditunjukkan dalam bentuk peningkatan kualitas dan kuantitas diri seperi pemahaman, daya pikir, pengetahuan. Prestasi belajar adalah perubahan tingkah laku yang dianggap penting yang diharapkan dapat mencerminkan perubahan yang terjadi sebagai hasil belajar siswa, baik yang berdimensi cipta, dan rasa maupun yang berdimensi karsa (Syah, 2006, p. 32).

Prestasi belajar merupakan target pengukuran kompetensi peserta didik dalam belajar yang ditunjukkan dengan skor. Chien (Feng, Fan, \& Yang, 2013, p. 52) me- 
ngemukakan bahwa learning achievement is the acquisition of knowledge or skills that are developed by subject matter, usually indicated by test scores or numerical value is assigned by teachers. Joshi \& Srivastava (2009, p. 34) menyatakan bahwa academic achievement could be defined as self-perception and selfevaluation of one's objective academic success. Nurkencana (2005, p. 62) mengemukakan bahwa prestasi belajar adalah hasil yang telah dicapai atau diperoleh anak berupa nilai mata pelajaran. Ditambahkan bahwa prestasi belajar merupakan hasil yang mengakibatkan perubahan dalam diri individu sebagai hasil dari aktivitas dalam belajar.

Motivasi merupakan salah satu aspek psikis dan merupakan potensi penting yang ada pada diri manusia. Miner (Lunenburg \& Ornstein, 2000, p. 88) menyatakan bahwa motivation has been defined as those processes within an individual that stimulate behavior and channel it in ways that should benefit the organization as a whole. Tanpa adanya motivasi kerja, seseorang pekerja termasuk guru, tidak akan bekerja dengan baik sehingga hasil pekerjaannya tidak akan memuaskan (Syakir \& Pardjono, 2015, p. 229).

Motivasi merupakan pendorong manusia dalam melakukan aktivitas-aktivitas dalam hidupnya (Sardiman, 2010, p.73). Motivasi merupakan keinginan yang terdapat pada seseorang individu yang merangsangnya untuk melakukan tindakan-tindakan atau sesuatu yang menjadi dasar atau alasan seseorang berprilaku. Lussier \& Achua (2010, p. 79) menyatakan, "Motivation is anything that affects behavior in pursuing a certain outcome". Siagian (2012, p. 142) bahwa motivasi adalah kejiwaan yang mendorong, mengaktifkan. Motivasi yang ada didalam diri seseorang merupakan kekuatan yang akan mewujudkan sesuatu perilaku guna mencapai tujuan selalu dikaitkan dengan pencapaian tujuan baik maupun tujuan buruk. Motivasi yang tinggi diperlukan agar tujuan organisasi dapat tercapai secara efektif.

Nawawi (2003, p. 328) berpendapat bahwa motivasi kerja adalah dorongan atau kehendak seseorang untuk melaksanakan tindakan atau kegiatan dalam ling- kup tugas-tugas yang merupakan pekerjaan/jabatannya di lingkungan sebuah organisasi. Seseorang orang yang melakukan suatu kegiatan tentu didorong oleh kebutuhan dan kegiatan yang dilakukannya mampu memenuhi kebutuhan tersebut. Motivasi kerja yang tinggi akan menghasilkan suatu pekerjaan yang memuaskan sehingga menjadi motivasi dalam mecapai prestasi pekerjaan. Emad (2014, p. 57) motivation is crucial and important in everything we do, especially at the work place. If we do not feel driven to do our job then the work will not be successfully accomplished.

Gomes (2003, p.180) mengatakan bahwa motivasi seorang pekerja untuk bekerja biasanya merupakan hal yang rumit, karena motivasi itu melibatkan faktor-faktor individual dan organisasional. Yang tergolong pada faktor-faktor yang sifatnya individual adalah kebutuhan-kebutuhan (needs), tujuan-tujuan (goals), sikap (attitudes), dan kemampuan-kemampuan (abilities). Sedangkan yang tergolong pada faktor-faktor yang berasal dari organisasi meliputi pembayaran atau gaji (pay), keamanan pekerja (job security), sesama pekerja (co-workers), pengawasan (supervision), pujian (praise), dan pekerjaan itu sendiri (job it self).

Sardiman (2010, p. 89) mengelompokkan motivasi menjadi dua bagian yaitu: (1) Motivasi instrinsik, yaitu motif-motif yang menjadi aktif atau berfungsinya tidak perlu dirangsang dari luar, karena dalam diri setiap individu ada dorongan untuk melakukan sesuatu. Sedangkan teori motivasi instrinsik menjelaskan kesadaran tentang keingintahuan, memahami lingkungan, kesadaran eksistensi diri dan kesadaran tentang merealisasikan kemampuan; (2) motivasi ekstrinsik, yaitu motif-motif yang aktif dan berfungsinya karena adanya perangsang dari luar. Motivasi ekstrinsik dalam dunia pendidikan dapat dilakukan oleh guru. Inusah \& Joseph $(2013$, p. 62) There are two main factors affecting teacher motivation namely; intrinsic and extrinsic factors. The extrinsic factors affecting teacher motivation are many and varied; however, for the purpose of this paper we have grouped them in five categories, namely; attractive remuneration, 
student discipline, good working conditions, favourable educational policies and high occupational status. Intrinsic motivators, on the other hand, are the "internal desires for personal and professional development and working in educational setting.

Sofyan \& Uno (2003, p. 106) menyatakan bahwa motivasi kerja seorang guru adalah suatu proses yang dilakukan untuk menggerakkan guru agar perilakunya dapat diarahkan pada upaya-upaya yang nyata untuk mencapai tujuan yang telah ditetapkan. Tujuan yang ingin dicapai berpengaruh dengan proses pemenuhan kebutuhan manusia. Menurut Ofejebe \& Ezugoh (2010, p. 401) teachers' motivation is a way of empowering teachers in the occupation and involves the perceptions, variables, methods, strategies and activities used by the management for the purpose of providing a climate that is conducive to the satisfaction of the various needs of the employees, so that they may become satisfied, dedicated and effective in performing their task.

Alam \& Farid (2011, p.298) menyatakan bahwa the motivation of teachers is affected by many factors. Amongst those factors a few are as under: (a) personal/social factors, (b) classroom environment, (c) socio economic status, (d) student's behavior, (e) examination stress, ( $f$ rewards/incentives, $(g)$ self confidence/ personality of teacher. Makna dari pernyataan tersebut adalah motivasi guru dipegaruhi oleh banyak faktor. Faktor-faktor tersebut diantaranya adalah faktor personal atau sosial: (a) lingkungan kelas, (b) status sosial ekonomi, (c) tingkah laku siswa, (d) tekanan ujian, (e) penghargaan atau harapan, (f) kepribadian atau percaya diri guru.

Disiplin adalah istilah yang disediakan untuk menggambarkan suatu kondisi pikiran, tata tertib, di sisi lain, hanyalah kondisi kejadian atau peristiwa. Kepatuhan sukarela terhadap pengaruh luar merupakan esensi dasar disiplin (Hughes \& Hughes, 2012, p. 243). Mathis \& Jackson (2009, p. 498) menyebutkan, disiplin adalah suatu bentuk pelatihan yang memberlakukan aturan organisasi.

Setyaningdyah, Kertahadi, \& Thoyib (2013, p.145) menyatakan bahwa work discipline is a policy to shift individuals in being self-responsible to comply the regulatory environment (organizations), Work discipline is a key issue in the operation of an organization as it assists the organization to accomplish specific targeted goals. Selanjutnya, Ardana, Mujianti, \& Utama (2011, p.134) menyatakan bahwa disiplin kerja merupakan suatu sikap menghormati, menghargai, patuh, dan taat terhadap peraturan-peraturan yang berlaku, baik yang tertulis maupun yang tidak tertulis serta sanggup menjalankannya dan tidak mengelak untuk menerima sanksi-sanksinya. Disiplin berkaitan erat dengan perilaku guru dan berpengaruh terhadap kinerja. Disiplin kerja yang dilakukan oleh guru bisa secara sukarela maupun terpaksa.

Kedisiplinan merupakan bagian dari karakteristik kepribadian yang sangat menentukan prestasi siswa. Karakteristik kepribadian memfokuskan kajiannya kepada lima faktor besar kepribadian diantaranya openness, extraversion, agreeableness, neoroticism, dan conscientiousness yang meliputi kesadaran akan kedisiplinan (Yusuf \& Sugandhi, 2011, p.99). Wahjosumidjo (2011, p. 188) menegaskan bahwa disiplin merupakan sikap mental yang mengandung kerelaan mematuhi semua ketentuan, peraturan dan norma yang berlaku dalam menunaikan tugas dan tanggung jawab.

Kedisiplinan siswa menurut Blandford (Aqib, 2011, p.116) menyatakan disiplin merupakan pengembangan mekanisme internal diri siswa sehingga siswa mengatur dirinya sendiri untuk mencapai kebutuhan. Kedisiplinan suatu sekolah ditentukan oleh nilai-nilai dan sikap warga sekolah termasuk kepala sekolah, guru dan siswa (Aqib, 2011, p.108). Kedisiplinan siswa dapat tercapai apabila seluruh komunitas sekolah menerapkan kedisiplinan diri, patuh terhadap norma dan tata tertib sekolah. Aturan yang telah ditetapkan oleh sekolah bukan untuk dilanggar namun untuk dipatuhi oleh semua warga sekolah.

\section{Metode Penelitian}

Penelitian ini menggunakan pendekatan kuantitatif dengan jenis penelitian 
korelasional. Penelitian ini dilaksanakan di SMA/MA di Kota Mataram Nusa Tenggara Barat yang terdiri dari 36 sekolah. Penelitian ini dilaksanakan mulai bulan Februari sampai bulan Mei tahun 2015. Data variabel bebas diambil pada bulan FebruariApril tahun 2015, sedangkan data variabel terikat diambil pada bulan Mei tahun 2015.

Populasi dalam penelitian ini adalah guru dan siswa/siswi SMA/MA yang ada di Kota Mataram. Jumlah populasi dalam penelitian ini 366 guru dan 4.321 siswa/ siswi SMA/MA di Kota Mataram. Teknik sampling yang digunakan adalah sampling puposive. Sampel penelitian ditentukan dengan cara melihat tabel Krejcie dan Morgan dengan taraf kesalahan 5\% sehingga diambil sampel sebanyak 182 guru dan 323 siswa/siswi.

Teknik pengumpulan data dalam penelitian ini adalah angket. Dalam penelitian ini angket digunakan untuk mengumpulkan data yang dibutuhkan mengenai motivasi kerja guru, disiplin kerja guru, dan kedisiplinan siswa. Penyusunan angket dilakukan dengan menggunakan pengukuran rating scale yang dimodifikasi. Responden diberi alternatif jawaban yaitu dengan memilih jawaban dari interval yang berjalan mulai dari 1 sampai 5 atau dari tidak pernah sampai dengan selalu. Pemberian skor dilakukan dengan melihat sifat butir.

Instrumen pengumpulan data pengaruh motivasi kerja guru, disiplin kerja guru, dan kedisiplinan siswa yang digunakan adalah lembar angket, sedangkan prestasi belajar siswa dilihat dari perolehan nilai rata-rata UN tahun ajaran 2014/2015. Penyusunan angket berdasarkan kajian teori kemudian dijabarkan menjadi indikator untuk membuat butir pernyataan pada angket.

Pengujian validitas dalam penelitian ini dilakukan dengan dua cara, yakni dengan tatap muka (expert judgment) dan dengan validitas isi (content validity). Sebelum butir-butir instrumen digunakan, dikonsultasikan terlebih dahulu kepada ahli (expert judgment) kemudian dilakukan uji coba terlebih dahulu kepada 30 responden.

Penghitungan uji validitas instrumen yang digunakan adalah Product moment.
Data ujicoba diolah dengan bantuan program komputer SPSS versi 17.0. Berdasarkan tabel bahwa nilai corrected item total correlation merupakan $\mathrm{r}$ hitung product momment. Dari dengan $n=30$ maka $r$ hitung dibandingkan dengan $r$ tabel sejumlah 0,361 untuk melihat kriteria validitas. Hasil uji validitas variabel motivasi kerja guru dari 24 butir pernyataan yang tidak valid 2 butir, variabel disiplin kerja guru dari 18 butir pernyataan yang tidak valid 2 butir, dan variabel kedisiplinan siswa dari 19 butir pernyataan yang tidak valid 2 butir karena angka yang dihasilkan lebih kecil dari 0,361.

Perhitungan reliabilitas uji coba instrumen dengan menggunakan rumus alphacronbach dengan bantuan software SPSS 17.0. Hasil uji reliabilitas instrumen kepada 30 responden koefisien korelasi variabel motivasi kerja guru sejumlah 0,833 , disiplin kerja guru sejumlah 0,810 , dan kedisiplinan siswa sejumlah 0,760 dengan demikian instrumen dinyatakan reliabel, karena hasil dari masing-masing variabel $\geq 0,600$.

Teknik analisis data yang digunakan dalam penelitian ini adalah analisis deskriptif. analisis deskriptif untuk mendeskripsikan data dengan melihat aspek ratarata (mean), varian data, atau modus data penelitian. Analisis deskriptif ini digunakan untuk memaparkan karakteristik data hasil penelitian dan menjawab permasalahan deskriptif.

Uji hipotesis pada penilitian ini menggunakan regresi linear sederhana dan regresi linier berganda. Sebelum melakukan uji regresi terlebih dahulu uji asumsi yakni uji normalitas, uji linearitas, dan uji multikolinearitas. Setelah uji asumsi pada regresi dilaksanakan, langkah selanjutnya adalah menganalisis data dengan menggunakan analisis regresi sederhana dengan bantuan program SPSS 17.0. Persamaan regresi sederhana $\mathrm{Y}=\mathrm{c}+\mathrm{bX}$. Persamaan regresi linear berganda dengan 3 variabel independen $\mathrm{Y}=\mathrm{c}+\mathrm{b} 1 \mathrm{X}_{1}+\mathrm{b} 2 \mathrm{X}_{2}+\mathrm{b} 3 \mathrm{X}_{3}$. Pengambilan keputusan, dengan ketentuan signifikansi $>0,05$ dan $\mathrm{t}$ hitung $<\mathrm{t}$ tabel maka Ho diterima (Ha ditolak), sedangkan signifikansi $\leq 0,05$ dan $\mathrm{t}$ hitung $>\mathrm{t}$ tabel maka Ho ditolak (Ha diterima). 


\section{Hasil Penelitian dan Pembahasan}

Data penelitian yang telah diperoleh selanjutnya dideskripsikan untuk masingmasing variabel. Dengan bantuan SPSS 17.0 diperoleh harga rerata $(\mathrm{M})$, simpangan baku (SD), modus (Mo) dan median (Md). Variabel motivasi kerja guru diperoleh nilai rerata (M) sejumlah 3,9297, standar deviasi (SD) sejumlah 0,47417, modus (Mo) sejumlah 3.87, dan median (Md) sejumlah 3,9200. Variabel disiplin kerja guru diperoleh nilai rerata $(\mathrm{M})$ sejumlah 3,7026, standar deviasi (standar deviation) sejumlah 0,45910, dan median (Md) sejumlah 3,7950. Variabel kedisiplinan siswa diperoleh nilai rerata $(\mathrm{M})$ sejumlah 3,8408, standar deviasi (SD) sejumlah 0,52303, modus (Mo) sejumlah 3.65, dan median (Md) sejumlah 3,7500. Variabel prestasi belajar siswa diperoleh nilai rerata (M) sejumlah 5,9906, standar deviasi (SD) sejumlah 1,00836, modus (Mo) sejumlah 5,78 , dan median sejumlah 5,7850.

Tabel 1. Distribusi Frekuensi Motivasi Kerja Guru

\begin{tabular}{lcccc}
\hline No. & $\begin{array}{c}\text { Kelas } \\
\text { Interval }\end{array}$ & $\begin{array}{c}\text { Nilai } \\
\text { Tengah }\end{array}$ & $\begin{array}{c}\text { Frekuensi } \\
\text { Absolut }\end{array}$ & $\begin{array}{c}\text { Frekuensi } \\
\text { Relatif }\end{array}$ \\
\hline 1. & $64-67$ & 65,5 & 1 & 0,549 \\
2. & $68-71$ & 69,5 & 1 & 0,549 \\
3. & $72-75$ & 73,5 & 5 & 2,747 \\
4. & $76-79$ & 77,5 & 14 & 7,692 \\
5. & $80-83$ & 81,5 & 32 & 17,582 \\
6. & $84-87$ & 85,5 & 37 & 20,33 \\
7. & $88-91$ & 89,5 & 58 & 31,868 \\
8. & $92-95$ & 93,5 & 26 & 14,286 \\
9. & $96-99$ & 97,5 & 8 & 4,396 \\
\multicolumn{2}{c}{ Jumlah } & & 182 & 100,00 \\
\hline
\end{tabular}

Tabel 2. Distribusi Frekuensi Disiplin Kerja Guru

\begin{tabular}{|c|c|c|c|c|}
\hline No & $\begin{array}{c}\text { Kelas } \\
\text { Interval }\end{array}$ & $\begin{array}{l}\text { Nilai } \\
\text { Tengah }\end{array}$ & $\begin{array}{c}\text { Frekuensi } \\
\text { Absolut }\end{array}$ & $\begin{array}{c}\text { Frekuensi } \\
\text { Relatif }\end{array}$ \\
\hline 1. & $50-52$ & 51 & 2 & 1,099 \\
\hline 2. & $53-55$ & 54 & 5 & 2,747 \\
\hline 3. & $56-58$ & 57 & 32 & 17,582 \\
\hline 4. & $59-61$ & 60 & 43 & 23,626 \\
\hline 5. & $62-64$ & 63 & 40 & 21,978 \\
\hline 6. & $65-67$ & 66 & 27 & 14,835 \\
\hline 7. & $68-70$ & 69 & 12 & 6,593 \\
\hline 8. & $71-73$ & 72 & 11 & 6,044 \\
\hline 9. & $74-76$ & 75 & 10 & 5,495 \\
\hline \multicolumn{2}{|c|}{ Jumlah } & & 182 & 100,00 \\
\hline
\end{tabular}

Tabel 3. Distribusi Frekuensi Kedisiplinan Siswa

\begin{tabular}{|c|c|c|c|c|}
\hline No. & $\begin{array}{c}\text { Kelas } \\
\text { Interval }\end{array}$ & $\begin{array}{c}\text { Nilai } \\
\text { Tengah }\end{array}$ & $\begin{array}{c}\text { Frekuensi } \\
\text { Absolut }\end{array}$ & $\begin{array}{c}\text { Frekuensi } \\
\text { Relatif }\end{array}$ \\
\hline 1. & $45-48$ & 46,5 & 2 & 0,619 \\
\hline 2. & $49-52$ & 50,5 & 2 & 0,619 \\
\hline 3. & $53-56$ & 54,5 & 18 & 5,573 \\
\hline 4. & $57-60$ & 58,5 & 58 & 17,957 \\
\hline 5. & $61-64$ & 62,5 & 88 & 27,245 \\
\hline 6. & $65-68$ & 66,5 & 78 & 24,149 \\
\hline 7. & $69-72$ & 70,5 & 44 & 13,622 \\
\hline 8. & $73-76$ & 74,5 & 20 & 6,192 \\
\hline 9. & $77-80$ & 78,5 & 10 & 3,096 \\
\hline 10. & $81-84$ & 82,5 & 3 & 0,929 \\
\hline \multicolumn{2}{|c|}{ Jumlah } & & 323 & 100,00 \\
\hline
\end{tabular}

Tabel 4. Distribusi Frekuensi Prestasi Belajar Siswa

\begin{tabular}{|c|c|c|c|c|}
\hline No. & $\begin{array}{c}\text { Kelas } \\
\text { Interval }\end{array}$ & $\begin{array}{c}\text { Nilai } \\
\text { Tengah }\end{array}$ & $\begin{array}{c}\text { Frekuensi } \\
\text { Absolut }\end{array}$ & $\begin{array}{c}\text { Frekuensi } \\
\text { Relatif }\end{array}$ \\
\hline 1. & $29-37$ & 33 & 1 & 2,778 \\
\hline 2. & $38-46$ & 42 & 9 & 25 \\
\hline 3. & $47-55$ & 51 & 13 & 36,111 \\
\hline 4. & $56-64$ & 60 & 7 & 26,923 \\
\hline 5. & $65-73$ & 69 & 4 & 11,111 \\
\hline 6. & $74-79$ & 77 & 2 & 5,5556 \\
\hline \multicolumn{2}{|c|}{ Jumlah } & & 36 & 100,00 \\
\hline
\end{tabular}

Data yang sudah diperoleh setelah dilakukan analisis statistik deskripsi, data penelitian kemudian di uji terlebih dahulu dalam berbagai uji persyaratan sebelum melakukan uji hipotesis penelitian. Pengujian persyaratan analisis ini meliputi uji normalitas, uji linearitas, dan uji multikolinearitas. Berikut ini akan dipaparkan hasil analisis hasil uji persyaratan analisis.

Uji normalitas yang dilakukan pada variabel motivasi kerja guru hasil output perhitungan SPSS 17,0 diperoleh nilai Kolmogorov-Smirnov $\mathrm{Z}$ sejumlah 0,663 dengan nilai signifikansi $(\mathrm{p})$ untuk variabel motivasi kerja guru adalah sejumlah 0,772 yang artinya variabel motivasi kerja guru berdistribusi normal. Nilai tersebut berada diatas $0,05$ ( $\mathrm{p}>0,05)$. Disiplin kerja guru nilai Kolmogorov-Smirnov Z sejumlah 0,828 degan nilai signifikansi (p) untuk disiplin kerja guru adalah sejumlah 0,499 yang artinya variabel disiplin kerja guru berdistribusi normal. Kedisiplinan suswa nilai Kolmogorov-Smirnov $\mathrm{Z}$ sejumlah 0,882 dengan 
nilai signifikansi (p) untuk variabel kedisiplinan siswa adalah sejumlah 0,418 yang artinya variabel kedisiplinan siswa berdistribusi normal. Prestasi belajar siswa nilai Kolmogorov-Smirnov Z sejumlah 0,666 dengan nilai signifikansi $(\mathrm{p})$ untuk variabel prestasi belajar siswa adalah sejumlah 0,767 yang artinya variabel prestasi belajar siswa berdistribusi normal. Nilai variabel motivasi kerja guru, disiplin kerja guru, kedisiplinan siswa dan prestasi belajar siswa berdistribusi normal karena hasil perhitungan masing-masing variabel diatas $0,05(\mathrm{p}>$ $0,05)$.

Uji linearitas dari output perhitungan SPSS 17,0 yang dilakukan terhadap variabel prstasi belajar siswa terhadap motivasi kerja guru diperoleh hasil sejumlah 0,632 > 0,05 . Variabel prestasi belajar siswa terhadap disiplin kerja guru sejumlah 0,886 > 0,05 . Variabel prestasi belajar siswa terhadap kedisiplinan siswa sejumlah 0,604 > 0,05 . Hal ini berarti hubungan antara variabel bebas dan variabel terikat bersifat linear.

Uji multikolinearitas dari output perhitungan SPSS 17,0 diperoleh hasil didapatkan nilai VIF untuk masing-masing variabel bebas $X_{1}$ sejumlah 1,116, $X_{2}$ sejumlah 1,756 dan $X_{3}$ sejumlah 1,622 adalah yang kurang dari 10 yang artinya tidak terjadi multikolinearitas antar variabel bebas.

Uji hipotesis pertama dari output perhitungan SPSS 17,0 bahwa nilai koefisien determinasi Adjusted $R$ Squre sejumlah 0,131 yang berarti kontribusi motivasi kerja guru terhadap prestasi belajar siswa sejumlah $13,1 \%$, sedangkan sisanya dipengaruhi oleh faktor lain. Diperoleh nilai signifikansi regresi sejumlah $0,017^{\mathrm{a}}(\mathrm{p}<0,05)$ yang berarti persamaan regresi signifikan. Hal ini berarti hipotesis diterima, yang berarti ada pengaruh yang signifikan secara tidak langsung antara motivasi kerja guru terhadap prestasi belajar siswa. Nilai koefisien untuk $\mathrm{X}_{1}$ adalah 0,840 , sedangkan nilai konstanta adalah 2,688 sehingga persamaan regresi linear gandanya adalah $\mathrm{Y}=2,688+0,840 \mathrm{X}_{1}$. Terlihat juga pada tabel 5 bahwa untuk uji signifikansi koefisien $\mathrm{X}_{1}$ 0,395, didapat nilai sig pada uji $t$ sejumlah $0,017<0,05$ yang berarti konstanta signifikan.
Tabel 5. Rangkuman Koefisien Regresi Hipotesis Pertama

Coefficients $^{\mathrm{a}}$

\begin{tabular}{|c|c|c|c|c|c|c|}
\hline & Unsta & andardized & Standardized & \multirow{3}{*}{$\begin{array}{ll} & \\
& \\
T\end{array}$} & \\
\hline & & & Coefficients & Coefficients & & \multirow[b]{2}{*}{ Sig. } \\
\hline & Model & B & Std. Error & Beta & & \\
\hline \multirow[t]{2}{*}{1} & (Constant) & 2.688 & 1.326 & & 2.027 & 7.051 \\
\hline & $\begin{array}{l}\text { motivasi kerja } \\
\text { guru }\end{array}$ & .840 & .335 & .395 & 2.509 & 9.017 \\
\hline
\end{tabular}

Dari persamaan regresi $\mathrm{Y}=2,688+$ $0,840 \mathrm{X}_{1}$ dapat diketahui bahwa koefisien regresi motivasi kerja guru $\left(\mathrm{X}_{1}\right)$ sejumlah 0,840 diartikan sebagai adanya prediksi bahwa setiap kenaikan motivasi kerja guru satu poin akan diikuti dengan peningkatan prestasi belajar siswa sejumlah 0,840, sedangkan nilai 2,688 adalah mengandung arti jika tidak ada faktor motivasi kerja guru maka prestasi belajar siswa adalah $\mathrm{Y}=$ 2,688.

Motivasi merupakan salah satu alat untuk meningkatkan dan mengarahkan kegiatan individu dalam mencapai tujuan organisasi. Motivasi kerja guru sangat dipengaruhi oleh faktor internal atau diri sendiri dan faktor eksternal seperti teman guru, penghargaan. Jika dihubungkan dengan literatur di bab II, terdapat kesesuaian menurut Sardiman (2010, p. 89) mengelompokkan motivasi menjadi dua bagian yaitu: (1) Motivasi instrinsik, yaitu motifmotif yang menjadi aktif atau berfungsinya tidak perlu dirangsang dari luar, karena dalam diri setiap individu ada dorongan untuk melakukan sesuatu. Sedangkan teori motivasi instrinsik menjelaskan kesadaran tentang keingintahuan, memahami lingkungan, kesadaran eksistensi diri dan kesadaran tentang merealisasikan kemampuan; (2) motivasi ekstrinsik, yaitu motifmotif yang aktif dan berfungsinya karena adanya perangsang dari luar. Motivasi ekstrinsik dalam dunia pendidikan dapat dilakukan oleh guru. Guru harus mengambil keputusan tentang apa yang harus diajarkan.

Motivasi kerja merupakan energi atau dorongan kuat yang menimbulkan perila- 
$\mathrm{ku}$ atau menyebabkan berubahnya perilaku untuk mencapai tujuan. Energi atau dorongan akan timbul jika seseorang memiliki tujuan yang harus dicapai. Besar kecilnya dorongan atau energi sangat tergantung urgensi pencapaian tujuan, maka motivasi kerja guru sangat diperlukan untuk meningkatkan prestasi belajar siswa karena siswa memerlukan motivasi dari guru. Motivasi kerja guru yang tinggi akan mencapai hasil yang baik karena guru akan mengeluarkan kemampuan mereka dengan sebaik-baiknya atau kinerja yang baik.

Motivasi sangat diperlukan oleh seorang guru dalam menjalankan tugas dan tanggungjawabnya. Kinerja seorang guru ditentukan bagaimana motivasinya dalam bekerja sebagai seorang guru. Guru sangat memerlukan banyak motivasi baik itu dari dalam diri maupun dari kepala sekolah, teman sejawat keluarga, dan lain-lain. Dalam sebuah sekolah, kepala sekolah yang mempunyai peran penting untuk terus-menerus memotivasi guru-guru sehingga kinerja dan tujuan dari sekolah dapat tercapai.

Uji hipotesis kedua dari output analisis regresi linear oleh SPSS 17,0 nilai koefisien determinasi Adjusted $R$ Square sejumlah 0,099 yang berarti kontribusi disiplin kerja guru terhadap prestasi belajar siswa sejumlah 9,9\% sisanya dipengaruhi oleh faktor lain. Diperoleh nilai signifikansi regresi sejumlah $0,035^{\mathrm{a}}(\mathrm{p}<0,05)$ yang berarti persamaan regresi signifikan. Hal ini berarti hipotesis kedua diterima, yang berarti ada pengaruh yang signifikan secara tidak langsung antara disiplin kerja guru terhadap prestasi belajar siswa. Nilai koefisien untuk $\mathrm{X}_{2}$ adalah 0,776, sedangkan nilai konstanta adalah 3,103 sehingga persamaan regresi linear gandanya adalah $\mathrm{Y}=3,103$ $+0,776 X_{2}$. Dari tabel 6 terlihat juga bahwa untuk uji signifikansi koefisien 0,353 , didapat nilai sig pada uji t sejumlah $0,035<0,05$ yang berarti konstanta signifikan.

Dari persamaan regresi $\mathrm{Y}=3,103+$ $0,776 \mathrm{X}_{2}$ dapat diketahui bahwa koefisien regresi disiplin kerja guru $\left(\mathrm{X}_{2}\right)$ sejumlah 0,776 diartikan sebagai adanya prediksi bahwa setiap kenaikan disiplin kerja guru satu poin akan diikuti dengan peningkatan prestasi belajar siswa sejumlah 0,776 , sedangkan 3,103 adalah mengandung arti jika tidak ada faktor motivasi kerja guru maka prestasi belajar siswa adalah $\mathrm{Y}=3,103$.

Tabel 6. Rangkuman Koefisien Regresi Hipotesis Kedua

Coefficients $^{\mathrm{a}}$

\begin{tabular}{|c|c|c|c|c|c|c|}
\hline & & \multicolumn{3}{|c|}{ Unstandardized Standardized } & \multirow[b]{3}{*}{$\mathrm{t}$} & \multirow[b]{3}{*}{ Sig. } \\
\hline & \multirow[b]{2}{*}{ Model } & \multicolumn{2}{|c|}{ Coefficients } & \multirow{2}{*}{$\frac{\text { Coefficients }}{\text { Beta }}$} & & \\
\hline & & $B$ & Std. Error & & & \\
\hline \multirow[t]{2}{*}{1} & (Constant) & 3.103 & 1.321 & & 2.350 & .025 \\
\hline & $\begin{array}{l}\text { disiplin kerja } \\
\text { guru }\end{array}$ & .776 & .352 & .353 & 2.202 & .035 \\
\hline \multicolumn{4}{|c|}{$\begin{array}{l}\text { a. Dependent Variable: rata-rata } \\
\text { prestasi siswa }\end{array}$} & & & \\
\hline
\end{tabular}

Disiplin kerja merupakan sesuatu yang utama dalam operasi dari suatu organisasi karena membantu organisasi untuk mencapai tujuan khusus yang ditargetkan. Disiplin kerja merupakan ketaatan seorang guru dalam mematuhi peraturan-peraturan yang berkaitan dengan tugasnya sebagai seorang guru. Jika dihubungkan dengan literatur di bab II, menurut Wirawan (2009, p.138) yang menyatakan bahwa disiplin merupakan sikap dan perilaku kepatuhan terhadap peraturan organisasi, prosedur kerja, kode etik dan norma budaya organisasi yang lainnya yang harus dipatuhi dalam memproduksi suatu produk dan melayani konsumen organisasi.

Disiplin kerja guru dikatakan penting karena jika disiplin kerja guru dalam sekolah baik maka tujuan dari sekolah akan mencapai hasil yang optimal. Dengan adanya disiplin kerja yang tinggi pada seorang guru akan menimbulkan dan mendorong timbulnya semangat kerja untuk mencerdaskan siswa.

Uji hipotesis ketiga dari output analisis regresi linear oleh SPSS 17,0 nilai koefisien determinasi Adjusted $R$ Square sejumlah 0,078 yang berarti kontribusi kedisiplinan siswa terhadap prestasi belajar siswa sejumlah $7,8 \%$ sisanya dipengaruhi oleh faktor lain. Diperoleh nilai signifikansi regresi sejumlah $0,100^{a}(p>0,05)$ yang berarti persamaan regresi tidak signifikan. Hal ini berarti hipotesis ketiga ditolak, yang berarti tidak ada pengaruh yang signifikan secara 
tidak langsung antara kedisiplinan siswa terhadap prestasi belajar siswa. Nilai koefisien untuk $\mathrm{X}_{3}$ adalah $-1,130$ sedangkan nilai konstanta adalah 10,299 sehingga persamaan regresi linear gandanya adalah $\mathrm{Y}=$ $10,299-1,130 X_{3}$. Dari tabel 7 terlihat juga bahwa untuk uji signifikansi koefisien X3, didapat nilai sig pada uji $\mathrm{t}$ sebesar 0,100 > 0,05 yang berarti konstanta tidak signifikan.

Tabel 7. Rangkuman Koefisien Regresi Hipotesis Ketiga

Coefficients $^{\mathrm{a}}$

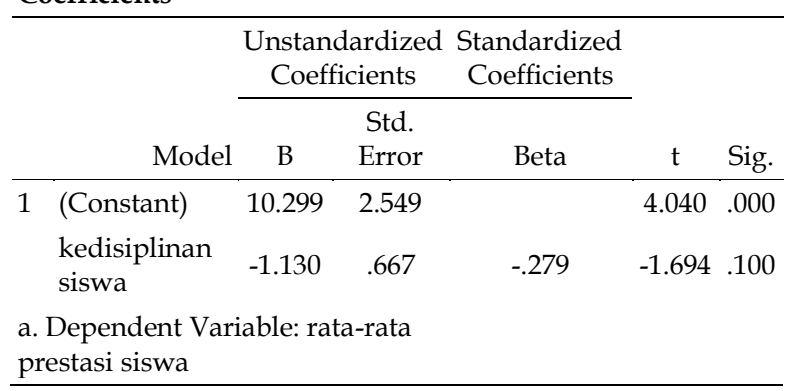

Dari persamaan regresi $Y=10,299$ $1,130 \mathrm{X}_{3}$ dapat diketahui bahwa koefisien regresi kedisiplinan siswa $\left(\mathrm{X}_{3}\right)$ sejumlah 0,617 diartikan sebagai adanya prediksi bahwa setiap penurunan kedisiplinan siswa satu poin akan diikuti dengan penurunan prestasi belajar siswa sejumlah $-0,617$, sedangkan 8,556 adalah mengandung arti jika tidak ada kedisiplinan siswa maka prestasi belajar siswa adalah $Y=8,556$.

Kedisiplinan siswa berpengaruh secara signifikan terhadap prestasi belajar siswa karena kedisiplinan terbentuk dari dalam diri dan dipengaruhi dari dalam diri dan faktor luar. Kedisiplinan siswa merupakan pengembangan bagaimana siswa tersebut mengatur dirinya sendiri dan hal tersebut berpengaruh terhadap intelektual seorang siswa. Kedisiplinan siswa merupakan ketaatan dan kepatuhan siswa terhadap berbagai peraturan dan tata tertib yang berlaku di sekolah. Dan masing-masing siswa tingkat kedisiplinannya berbedabeda. Kedisiplinan siswa akan tertanam dengan baik jika dari pihak sekolah bekerja sama dengan orang tua untuk selalu memberikan pengarahan-pengarahan dan tidak hanya memberikan arahan jika melanggar suatu hal maka hukuman atau sanksinya seperti ini. Siswa yang memiliki kedisiplinan yang tinggi dikarenakan adanya kesadaran dalam diri siswa mengenai aturanaturan yang harus dipatuhi dan ditaati. Jika dihubungkan dengan literatur di bab II terdapat kesesuaian antara pendapat di atas dengan teori Blandford (Aqib, 2011, p. 116) menyatakan bahwa kedisiplinan siswa merupakan pengembangan mekanisme internal diri siswa sehingga siswa mengatur dirinya sendiri untuk mencapai kebutuhan.

Uji hipotesis keempat dari output analisis regresi linear oleh SPSS 17,0 nilai koefisien determinasi Adjusted $R$ Square sejumlah 0,340 yang berarti kontribusi motivasi kerja guru, disiplin kerja guru dan kedisiplinan siswa terhadap prestasi belajar siswa sejumlah $34 \%$ sisanya dipengaruhi oleh faktor lain. Diperoleh nilai signifikansi regresi sejumlah $0,001^{a}(p<0,05)$ yang berarti persamaan regresi signifikan. Hal ini berarti hipotesis keempat diterima, yang berarti ada pengaruh yang signifikan secara tidak langsung antara motivasi kerja guru, disiplin kerja guru dan kedisiplinan siswa terhadap prestasi belajar siswa. Nilai koefisien untuk $\mathrm{X}_{1}$ sejumlah $1,108, \mathrm{X}_{2}$ sejumlah 0,995, dan $X_{3}$ sejumlah $-0,205$, sedangkan nilai konstanta adalah $-1,129$ sehingga persamaan regresi linear gandanya adalah $\mathrm{Y}=-1,129+1,108 \mathrm{X}_{1}+0,995 \mathrm{X}_{2}-$ $0,2055 \mathrm{X}_{3}$. Pada tabel 8 terlihat juga bahwa untuk uji signifikansi koefisien $\mathrm{X}_{1}$, didapat nilai sig pada uji t sebesar 0,001 <0,05 yang berarti konstanta signifikan. Pada uji signifikansi koefisien $\mathrm{X}_{2}$, didapat nilai sig pada uji $t$ sebesar $0,023<0,05$ yang berarti konstanta signifikan. Pada uji signifikansi koefisien $\mathrm{X}_{3}$, didapat nilai sig sebesar 0,548 > 0,05 yang berarti konstanta tidak signifikan. Berdasarkan hasil signifikansi maka, secara bersama-sama $X_{1}$ dan $X_{2}$ berpengaruh terhadap perubahan $Y$, dan $X_{3}$ tidak dapat berpengaruh secara bersama-sama terhadap perubahan $\mathrm{Y}$.

Dari persamaan regresi $\mathrm{Y}=-1,129+$ $1,108 \mathrm{X}_{1}+0,955 \mathrm{X}_{2}-0,205 \mathrm{X}_{3}$ dapat diketahui bahwa koefisien regresi motivasi kerja guru $\left(\mathrm{X}_{1}\right)$, disiplin kerja guru $\left(\mathrm{X}_{2}\right)$ dan kedisiplinan siswa $\left(X_{3}\right)$ sejumlah 1,108, 0,955 dan 0,205 diartikan sebagai adanya prediksi 
bahwa setiap kenaikan motivasi kerja guru dan disiplin kerja guru satu poin akan diikuti dengan peningkatan prestasi belajar siswa sejumlah 0,521, 0,435 serta setiap penurunan kedisiplinan siswa satu poin akan diikuti dengan penurunan prestasi belajar siswa sejumlah -0,205, sedangkan 1,129 adalah mengandung arti jika tidak ada peningkatan faktor motivasi kerja guru, disiplin kerja guru, dan kedisiplinan siswa maka prestasi belajar siswa adalah $\mathrm{Y}=$ 1,129 .

Tabel 8. Rangkuman Koefisien Regresi Hipotesis Keempat

\begin{tabular}{|c|c|c|c|c|}
\hline \multirow[b]{2}{*}{ Model } & \multicolumn{2}{|c|}{$\begin{array}{l}\text { Unstandardized } \\
\text { Coefficients }\end{array}$} & $\begin{array}{l}\text { Standardized } \\
\text { Coefficients }\end{array}$ & \multirow[b]{2}{*}{ Sig } \\
\hline & B & Std. Error & Beta & \\
\hline 1 (Constant) & -1.129 & 3.073 & & -.367 .716 \\
\hline $\begin{array}{l}\text { motivasi kerja } \\
\text { guru }\end{array}$ & 1.108 & .309 & .521 & 3.590 .001 \\
\hline $\begin{array}{l}\text { disiplin kerja } \\
\text { guru }\end{array}$ & .955 & .400 & .435 & 2.388 .023 \\
\hline $\begin{array}{l}\text { kedisiplinan } \\
\text { siswa }\end{array}$ & -.205 & .337 & -.106 & -.606 .548 \\
\hline
\end{tabular}

Prestasi belajar siswa dipengaruhi oleh berbagai faktor seperti motivasi kerja guru, disiplin kerja guru, kedisiplinan siswa, dan lain-lain. Prestasi belajar siswa dapat dipengaruhi oleh motivasi kerja guru dikarenakan siswa membutuhkan motivasi baik itu dari guru dan kedua orang tua. Siswa membutuhkan motivasi kerja guru mampu meningkatkan prestasi belajar siswa karena jika motivasi kerja guru baik maka akan menghasilkan kinerja yang optimal bagi guru dalam menjalankan tugasnya sebagai seorang guru. Disiplin kerja guru yang baik akan menjadikan organisasi atau sekolah mencapai tujuannya. Dan kedisiplinan siswa yang tinggi timbul dari rasa kesadaran seorang siswa mengenai taat pada aturan dan tata tertib yang ada di sekolah. Jika ketiga variabel motivasi kerja guru, disiplin kerja guru, dan kedisiplinan siswa baik dan optimal maka akan meningkatkan prestasi belajar siswa. Jika dihubungkan dengan literatur di bab II, menurut Slameto (2013, p.54) yang menyatakan bahwa faktor-faktor yang mempengaruhi hasil belajar banyak jenisnya, tetapi digolongkan menjadi dua golangan yaitu (a) faktor intern dan (b) faktor eksteren. Faktor internal adalah faktor yang ada didalam individual, sedangkan faktor eksternal adalah faktor yang ada di luar individu.

\section{Simpulan}

Berdasarkan hasil penelitian dan pembahasan yang telah dipaparkan, maka dapat disampaikan simpulan sebagai berikut. Pengaruh antara motivasi kerja guru terhadap prestasi belajar siswa SMA/MA di Kota Mataram sejumlah 13,1\%. Pengaruh antara disiplin kerja guru terhadap prestasi belajar siswa SMA/MA di Kota Mataram sejumlah 9,9\%. Pengaruh antara kedisiplinan siswa terhadap prestasi belajar siswa SMA/MA di Kota Mataram sejumlah $7,8 \%$. Pengaruh motivasi kerja guru, disiplin kerja guru dan kedisiplinan siswa secara bersama-sama mempengaruhi prestasi belajar siswa SMA/MA di Kota Mataram sejumlah $34 \%$.

Adapun saran yang dapat dikemukakan antara lain: (1) bagi guru, agar guru senantiasa berusaha meningkatkan motivasi kerja dan disiplin kerja dalam melaksanakan tugasnya sebagai guru terutama pada saat pembelajaran di kelas; (2) bagi siswa, untuk senantiasa berusaha meningkatkan kedisiplinan dalam melaksanakan tugas sebagai siswa dan siswi di sekolah.

\section{Daftar Pustaka}

Alam, M. T., \& Farid, S (2011). Factors affecting teachers motivation. Journal of business and Social Science, 2, 298-304.

Ardana, I. K., Mujianti, N. W., \& Utama, M. (2012). Manajemen sumber daya manusia. Yogyakarta: Graha Ilmu.

Aqib, Z. (2011). Pendidikan karakter membangun perilaku positif anak bangsa. Bandung: Yrama Widya.

Emad, M. J. A. (2014). Teacher motivation: A study of work motivation of the primary stage teachers in Jordan. Journal of applied Psychology, 3, 57-61. 
Feng, H. Y., Fan, J. J., \& Yang, H. Z. (2013).

The relationship of learning motivation and achievement in efl: gender as an intermediated variable. Educational Research International, 2, 5058.

Gomes, F. C. (2003). Manajemen sumber daya manusia. Yogyakrta : Andi Offset.

Hughes, A. G., \& Hughes, E. H. (2012). Learning $\mathcal{E}$ teaching pengantar psikologi pembelajaran modern. (Terjemahan SPA Team Work). Bandung: Nuansa (Buku asli diterbitkan tahun 2003).

Inusah, S., \& Joseph, S. A. (2013). Teacher motivation and identity formation: issues affecting professional practice. Journal of Educational Studies, Trends $\mathcal{E}$ Practices, 3, 58-74.

Joshi, S., \& Srivastava, R. (2009). Selfesteem and academic achievement of adolescents. Journal of the Indian Academy of Applied Psychology, 35, 3339.

Lunenburg, F. C., \& Ornstein, A. C. (2000). Educational administration: Concepts and practices (3rd ed.). Belmont: Wadsworth.

Lussier, R. N., \& Achua, C. F. (2010). Leadership theory, application, E skill development ( $4^{\text {th }}$ ed.). Mason: Cengage Learning.

Mathis, R. L., \& Jackson, J. H. (2006). Human resource management. (13th ed.). Mason: Cengage Learning.

Mulyasa, E. (2009). Standar kompetensi dan sertifikasi guru. Bandung: Remaja Rosda Karya.

Nawawi, H. (2003). Kepemimpinan mengefektifkan organisasi. Yogyakarta: Gajahmada University Press.

Nurkencana. (2005). Evaluasi hasil belajar mengajar. Surabaya: Usaha Nasional.

Ofejebe, W. N., \& Ezugoh, T. C. (2010). Teachers' motivation and its influence on quality assurance in the Nigerian education system. Journal of Multi Disciplinary, 4, 398-417.

Sardiman. (2010). Interaksi dan motivasi belajar mengajar. Jakarta: PT Raya Grafindo Akasara.

Setyaningdyah, E., Kertahadi, U. N., \& Thoyib, A. (2013). The effects of human resource competence, organisational commitment and transactional ledearship on work discipline, job satisfaction and employee's performance. Journal of contemporary Research in Business, 5, 140-153.

Siagian, S. P. (2012). Teori motivasi dan aplikasinya. Jakarta: PT Rineka Cipta.

Slameto. (2013). Belajar dan faktor-faktor yang mempengaruhinya. Jakarta: PT Rineka Cipta.

Sofyan, H., \& Uno, B. H. (2003). Teori motivasi dan aplikasinya dalam penelitian. Gorontalo: Nurul Janah.

Suwatno, \& Priansa, D. J. (2011). Manajemen SDM dalam organisasi publik dan bisnis. Bandung: Alfabeta.

Syah, M. (2006). Psikologi pendidikan dengan pendekatan baru. Bandung: PT Remaja Rosda Karya.

Syakir, M. J., \& Pardjono. (2015). Pengaruh kepemimpinan kepala sekolah, motivasi kerja dan budaya organisasi terhadap kompetensi guru SMA. Jurnal Akuntabilitas Manajemen Pendidikan, 3(2), 226-240.

Wahjosumidjo. (2011). Kepemimpinan kepala sekolah. Jakarta: PT Raja Grafindo Persada.

Wirawan. (2009). Evaluasi kinerja sumber daya manusia; teori aplikasi dan penelitian. Jakarta: Salemba Empat.

Yusuf, S. L. N., \& Sugandhi, N. M. (2011). Perkembangan peserta didik. Bandung: Grafindo Persada. 